\title{
The Fukushima Daiichi Nuclear Power Plant Accident: A Provisional Analysis and Survey of the Government's International \&t Domestic Response: Verification and the Road to Recovery in 2012
}

\section{Kanami Ishibashi'}

This report is a follow-up to a short note in the 2011 Asian Yearbook of International Law on the legal developments resulting from the Fukushima Daiichi Nuclear Power Plant accident in 2011. ${ }^{2}$ On 23 July 2012, the final report of the Investigation Committee on the Accident at the Fukushima Nuclear Power Stations was submitted to the Prime Minister. This final report is a supplement to the provisional report referred to in the 2011 volume.

The final report concludes that there were seven major problems in the response to the accidents as follows:

(1) Tokyo Electric Power Company's (TEPCO) response to the accident and damage to the plant;

(2) Responses to the accident by the government and other bodies;

(3) Measures to prevent the spread of damage;

(4) Accident prevention measures and emergency preparations;

1 Associate Professor, Tokyo University of Foreign Studies.

2 Kanami Ishibashi, The Fukushima Daiichi Nuclear Power Plant Accident: A Provisional Analysis and Survey of the Government's International and Domestic Response, 17 Asian YeArbook of International LAW 149-157 (2011), available at http://www.dilafoundation.org/uploads/1/1/2/8/11284804/asybil_vol17_149-157. pdf. 
(5) Nuclear safety regulatory bodies' responses;

(6) TEPCO competence; and

(7) Compliance with international practices such as IAEA safety standards.

To prevent such accidents in the future, the report found that it was necessary to do the following: establish fundamental and effective disaster preventive measures; find out how to respond to complex disasters; change attitudes towards risk; focus on the disaster victims' point of view; create a sense of urgency within administrative agencies and TEPCO; create a government crisis management system; improve information and risk communication; and establish a culture of safety critical for saving lives. The Committee concluded that further investigation into the causes of the accident and resulting damage was necessary.

The Committee also recommended establishing: basic safety measures and emergency protocols; safety measures regarding nuclear power generation; nuclear emergency response systems; damage prevention and mitigation; compliance with international practices and relevant organizations; and continued investigation into the causes of the accident and resulting damage.

Prime Minster Noda accepted this final report and promised to make efforts to avoid future accidents by fully adhering to the report. The Committee ceased its mission and was dissolved.

Shortly thereafter, the Nuclear Regulation Authority (NRA) was established by the Act for the Establishment of the Nuclear Regulation Authority (Act No. 47 of June 27, 2012). Article 3 of the Act describes the mission of NRA as follows:

The mission of the Nuclear Regulation Authority shall be to use nuclear energy (the mission shall include affairs concerning refining activities, fabricating and enrichment activities, interim storage activities, reprocessing activities and waste disposal activities concerning nuclear energy, as well as regulations on reactors, and affairs concerning regulations for implementing safeguards based on international commitments, and other regulations for ensuring the peaceful use of nuclear energy) for the purpose of contributing to the protection of the life, health, and property of citizens and the preservation of the environment and national security of Japan. 
The Committee is expected to control all nuclear energy related processes in an integrated way, from use to disposal of nuclear substances. It is also noteworthy that such control is expected to contribute to the protection of life, health and property, the environment, and the national security of Japan.

\section{DE FACTO NATIONALIZATION OF TEPCO AND THE INDEPENDENCE OF THE NRA}

The Committee was established pursuant to Article 3 of the National Government Organization Act, which ensures independence from the Government and electricity companies which have vested interests, though the Chairman is appointed by the Prime Minister (Art. 7(1)). Such a provision for independence is significant since TEPCO, which operated the Fukushima Nuclear Power Plants, was de facto nationalized on 31 July 2012. The Nuclear Damage Compensation Facilitation Corporation, which was established by the Nuclear Damage Compensation Facilitation Corporation Act (Act No. 94 of August 10, 2011) invested a trillion yen in TEPCO and obtained $50.11 \%$ of the voting share (at present) and $75.84 \%$ of the total stock including non-voting share, which would be converted to voting shares if TEPCO fails to recover and rebuild its business. The government will cease to hold shares by deciding that TEPCO manages itself.

\section{SHUTDOWN OR RESTART OF OTHER NUCLEAR FACILITIES}

On 5 May 2012, Tomori Nuclear facilities shut down for periodic review, bringing all its nuclear power plants to a halt. Such shutdowns have never happed since 1970 .

The government tried to reactivate the nuclear power station. The first activation was carried out in Ohi Nuclear power station, which is located in Fukui prefecture and has been owned by the Kansai Electric Power Company since the Fukushima Nuclear Power Plant Accidents occurred. According to a press report, "The restarting of reactor No. 3 at the Ohi nuclear plant was ordered two weeks ago by Prime Minister Yoshihiko Noda, in a decision that has spurred growing public protests." 3 The govern-

3 Martin Fackler, In Japan, First Reactor Is Restarted Since Quake, N.Y. Times, July 1, 2012, available at http://www.nytimes.com/2012/07/02/world/asia/japan- 
ment believes that if the Ohi Nuclear power stations are not reactivated, there might be a power shortage in the Kansai area, particularly in summer, when people need more electricity for air conditioning. ${ }^{4}$

However, there was strong opposition to the reactivation. Local residents (189 plaintiffs) sought an injunction before the Fukui District Court to prevent the government from restarting the Ohi nuclear power station in November $2012,{ }^{5}$ since they believed that safety was not yet ensured.

restarts-a-nuclear-reactor.html?_r=1.

4 Yoshihiko Noda, Japan Prime Minister, Press Conference by Prime Minister Yoshihiko Noda (June 8, 2012), available at http://japan.kantei.go.jp/noda/ statement/201206/08kaiken_e.html. The Prime Minister stated as follows:

I would like to share my thoughts directly with the people of Japan on the resumption of Units 3 and 4 of Oi [sic] Nuclear Power Station. [...]

As we approach the summer, when electricity demand is at its peak, the time is coming upon us to make a conclusion. To protect the lives of the people - this was my one and only criteria in making a judgment on this issue that has split public opinion in two. My conviction is that it is the ultimate responsibility of the Government to protect the lives of the people.

In addition, he explained the necessity of activating the Ohi nuclear power plant as follows:

In order to lead prosperous and decent lives, cheap and stable electricity is indispensable. Japanese society will not be able to function if there is a decision to permanently halt nuclear power generation, which has accounted for approximately $30 \%$ of our total electricity supply, or if nuclear power generation remains halted.

If this were a matter of saving electricity by a few percentage points, then perhaps we could somehow manage if everyone pooled their efforts. However, Kansai's electricity supply-demand gap of as high as $15 \%$ is a level that was not experienced even in eastern Japan last year, and realistically, I believe it is a huge hurdle to overcome.

5 See Greenpeace, Outline of Judgment on Claim for Injunction on Operation of No. 3 and No. 4 Units at Ohi Nuclear Power Plant Fukui District Court, May 21 2014, available at http://www.greenpeace.org/japan/Global/japan/pdf/Ohi_ruling_gpj. pdf. A detailed analysis of this judgment and its possible effects on Japanese nuclear energy policy will be conducted in the following 2014 yearbook (vol. 20). 


\section{RELATED ENACTMENTS TOWARDS RECOVERY FROM THE NUCLEAR ACCIDENT AND PROGRESS OF AND COMPENSATION TO THE VICTIMS}

As described in my earlier note in the 2011 Yearbook, two fundamental laws, the Basic Act on Reconstruction in response to the Great East Japan Earthquake and the Act for Establishment of the Reconstruction Agency, were enacted in 2011. Accordingly, in early 2012, the Reconstruction Agency was established as the successor to the "Reconstruction Headquarters in Response to the Great East Japan Earthquake," which coordinated initial response efforts in the immediate aftermath of the disaster. ${ }^{6}$ The government also enacted several important laws for reconstruction and support for the victims: the Act for Special Measures Concerning the Reconstruction and Recovery of Fukushima (Act No. 25 of March 30, 2012), the Act for the Establishment of the Nuclear Regulation Authority (Act No. 47 of June 27, 2012), ${ }^{7}$ and the Nuclear Accident Child Victims' Support Law (Act No. 48 of June 27, 2012).

The Act for Special Measures Concerning the Reconstruction and Recovery of Fukushima provides that special measures should be taken for the reconstruction and recovery of the Fukushima area that was exposed to the radiation, including the termination of evacuation of original residents (Art. 7-17), exemption of tax (Art. 18, 19), support for industries (Art. 53-37), and the generation of new employment on site (Art. 67, 68).

The Act for Establishment of the Nuclear Regulation Authority is the basis for establishing the NRA, whose mission has already been described above. The Act authorizes the NRA to exercise huge and comprehensive power over not only supervision on any measures related to the Fukushima Nuclear Power plants, but also the setting up of new safety standards for the operation of other nuclear power plants in Japan, by examining nuclear power plant facilities and manuals for operation and risk management in cases of emergencies, and investigating their compliance with the safety

6 Reconstruction Agency of Japan, available at http://www.reconstruction.go.jp/ english/topics/about-us.html.

7 Act for the Establishment of the Nuclear Regulation Authority, Act No. 47, translated in Extra Official Gazette of June 27, 2012, available at http://www.nsr. go.jp/data/000067231.pdf. 
standard as conditions for operating that facility. ${ }^{8}$ More importantly, the NRA is required to "integrally govern affairs for developing and implementing measures necessary for ensuring safety in the use of nuclear energy based on established international criteria (such affairs shall include those concerning refining activities, fabricating and enrichment activities, interim storage activities, reprocessing activities and waste disposal activities concerning nuclear energy, as well as regulations on reactors, and those concerning regulations for implementing safeguards based on international commitments, and other regulations for ensuring the peaceful use of nuclear energy)" (Art. 1) and it is expected to coordinate its policy and measures with that of IAEA. To be certain, there are several Conventions under the initiative of the IAEA and the NRA has submitted the National Report under the Convention on Nuclear Safety ${ }^{9}$ and Joint Convention on the Safety of Spent Fuel Management and on the Safety of Radioactive Waste Management to the IAEA, ${ }^{10}$ which demonstrates a form of coordination with IAEA.

The Nuclear Accident Child Victims' Support Law provides-bearing in mind that children (either born and unborn (children in the womb)) are especially vulnerable to the effects of radiation-for ensuring medical care, support for school attendance, ensuring food safety at home and in schools, maintenance of physical and mental health, and support for children living separate from their families (Art. 8). It obliges the government to take necessary measures, including the reduction or exemption of medical costs for child victims (Art. 13). This Act not only addresses children but also victims in general, although the extent of protection for adults is weaker than that for children. For example, it provides support for victims who plan to return to their original residence (Art. 10) and requires the government to take necessary measures to supply medical care for all victims. This is understandable as children are among the most

8 Nuclear Regulation Authority of Japan, Regulatory Requirement, available at https://www.nsr.go.jp/english/regulatory/index.html.

9 Nuclear Regulation Authority of Japan, Convention on Nuclear SAFETy: NATIONAL Report Of JAPAN, available at http://www.nsr.go.jp/english/ cooperation/conventions/CNS.html.

10 Nuclear Regulation Authority of Japan, Joint Convention on the Safety of Spent Fuel Management and on the Safety of Radioactive Waste Management, http://www.nsr.go.jp/english/cooperation/conventions/JC.html. 
vulnerable victims. It is also important to support all the victims to protect the vulnerable in the community.

On the other hand, there are several cases that have been brought to court by some victims who were not satisfied with the government's efforts. For example, the victims who were forced to resettle in other areas took legal action against TEPCO seeking compensation for forced resettlement and for the loss of land, house, other properties and their hometown. ${ }^{11} \mathrm{~A}$ victim also sued TEPCO seeking compensation for his wife's death, in that she committed suicide by self-immolation, after suffering from forced resettlement and depression due to the loss of home and so on. ${ }^{12}$ Moreover on 5 March 2012, 42 shareholders sued the directors of TEPCO in a form of a shareholder lawsuit for 5,500 billion yen in damages. ${ }^{13}$ On 21 December 2012, eight American sailors who suffered from exposure to radiation during decontamination work known as "Operation Tomodachi" sued TEPCO in the US federal court (San Diego) for compensation concerning the disclosure of information relevant to risks. ${ }^{14}$

It is expected that such lawsuits might increase in the following years. This, and the results of the above lawsuits, will be discussed in the next volume of the Yearbook.

\section{OPERATION TO ELIMINATE OR MITIGATE THE EFFECTS OF RADIATION: EFFORTS TO INTRODUCE THE NEW ALPS SYSTEM}

It is critical to eliminate or reduce the level of radiation at the site of Fukushima Nuclear Power Plant. One approach is using the so-called SARRY

11 Japanese Compensation Judgment, available at http://media.wix.com/ugd/47f75 3_761ace2122a5490baf1a5b9318a2080a.pdf.

12 Kyung Lah, Husband of Fukushima Suicide Victim Demands Justice, CNN, June 21, 2012, available at http://edition.cnn.com/2012/06/20/world/asia/japanfukushima-suicides/index.html?hpt=ias_t2.

13 Jaclyn Belczyk, Japan Power Company Shareholders File Record Lawsuit over Fukushima Nuclear Crisis, JuRIst, Mar. 5, 2012, available at http://jurist.org/ paperchase/2012/03/japan-power-company-shareholders-suing-over-fukushimanuclear-crisis.php.

14 Tom Watkins and Lateef Mungin, U.S. Navy Sailors Sue Japan over Nuclear Accident, CNN, Dec. 29, 2012, available at http://edition.cnn.com/2012/12/28/ world/asia/japan-fukushima-lawsuit/. 
(simplified active water retrieval and recovery) system, which is a simplified active water retrieval and recovery system and uses zeolite to absorb cesium isotopes and reduce radiation levels to 1 millionth. This approach was used to eliminate radiation-contaminated water, but a drawback is that it only removes cesium from the contaminated water. ${ }^{15}$

The system is inadequate because it can only deal with one substance, cesium. Therefore, in 2012, a new system called ALPS (Advanced Liquid Processing System) was developed and activated to purify the contaminated water. ALPS can retrieve and absorb 62 radionuclides to the extent of meeting safety standards provided by law, ${ }^{16}$ although even the water treated by the ALPS must be kept in water storage tanks.

While ALPS was expected to complement SARRY, its full-scale operation did not happen in 2012 since the storage container for the radioactive waste extracted from the contaminated water was not strong enough. Therefore, in 2012, the SARRY system continued to serve as the main method for treating the contaminated water.

However, depending only on SARRY to treat contaminated water is inadequate because even treated water contains radioactive substance, such as extremely toxic strontium. Several incidents of radioactive water leaking from the Fukushima Daiichi Nuclear Power Plant occurred during 2012, including cases in February, March, April, August, and November. In all of these cases, there were spills of contaminated water which contained highly concentrated strontium.

In the February and March cases, it was found that some contamination flowed into the sea. In particular, in March, 120 tons of contaminated water flowed from the joint section of pipes which is used for the treatment

15 Kazuaki Nagata, TEPCO Makes Little Headway in Decontaminating Water, The Japan Times, Aug. 5, 2011, available at http://www.japantimes.co.jp/ news/2011/08/05/national/tepco-makes-little-headway-in-decontaminatingwater/\#.VPRDnWdEjY8.

16 For further details on AlPS, see Tokyo Electric Power Company, Multinuclide Removal Equipment Confirmatory Testing, Installation and CHARACTERISTICS OF RADIOACTIVE WASte, available at http://www.tepco.co.jp/ en/nu/fukushima-np/roadmap/images/m120625_01-e.pdf. 
of contained water. Eighty liters of this water, with a very high concentration of strontium, leaked into the sea though the trench. ${ }^{17}$

In the November case, there was no leakage into the surrounding sea. But a new problem came to light regarding the shortage of tanks to contain the treated water. Since even treated water still contains high toxic strontium, it must be stored under strictly controlled conditions. However, the surrounding underground water nearby the Fukushima Daiichi Nuclear Power Plant flowed into the facilities and mixed with the contaminated water, so that the volume of contaminated water which needs to be treated is increasing on a daily basis and is beyond the capability of the SARRY system and tanks to treat and store. To deal with this problem, wells were made to pump up the underground water in order to reduce the surrounding underground water and prevent it from flowing into the facilities and mixing with the contaminated water. ${ }^{18}$

\section{CONCLUSION}

In 2012, there was certainly some progress in the investigation of the Fukushima Daiichi Nuclear Power Plant accident and enactments of laws necessary for recovery. In particular, it is notable that from the tragic lessons learned, a new organization, the NRA, which is independent from the government and electricity companies, was established to supervise any measures dealing with accidents. As described above, the NRA is required to play an active role in the safety operations of nuclear power plants and comply with international standards; its mission is very important in terms of the implementation of international law.

However, whether or not the huge and comprehensive authority of the NRA is utilized properly in a way that the law originally intended requires examination. If the NRA loses its independence from the government or

17 福島第一污染水120 t 漏れる…海へ一部流出か [Leakage of Contaminated Water at Fukushima Daiichi Nuclear Power Plant; Partially Spilled into the Surrounding Sea?], (Japanese) Yomiuri Shimbun, Mar. 26, 2012, available at http://www. yomiuri.co.jp/feature/TO000303/20120326-OYT1T01018.html.

18 井戸掘削工事始まる 污染水発生量抑制へ対策 [Making Wells to Reduce Contaminated Water Caused by Mixture with the Surrounding Underground Water], Токуо Shimbun, Nov. 24, 2012, available at http://www.tokyo-np.co.jp/ article/feature/nucerror/condition/list/CK2012112402000159.html. 
electricity companies, this could have tremendous effects on the whole structure of Japanese nuclear policy, including the decommissioning of existing nuclear reactors. Actually, apart from the aftermath of accidents, it is becoming unrealistic for Japan to decommission all the nuclear power plants and, in fact, in 2012, two reactors in the Ohi Nuclear Power Plant were reactivated despite huge public protest. At the time this decision was made, the NRA was neither operational nor in a position to have a leading role. However, it remains unclear whether the NRA can play a decisive role in such future cases where there is no consensus concerning the safety of nuclear facilities.

Further verification of the role of the NRA and the guarantee of nuclear safety in Japan, especially in terms of international standards under the IAEA Conventions, will be analyzed in the following comment which is to be included in the following 2013 volume of this Yearbook. 